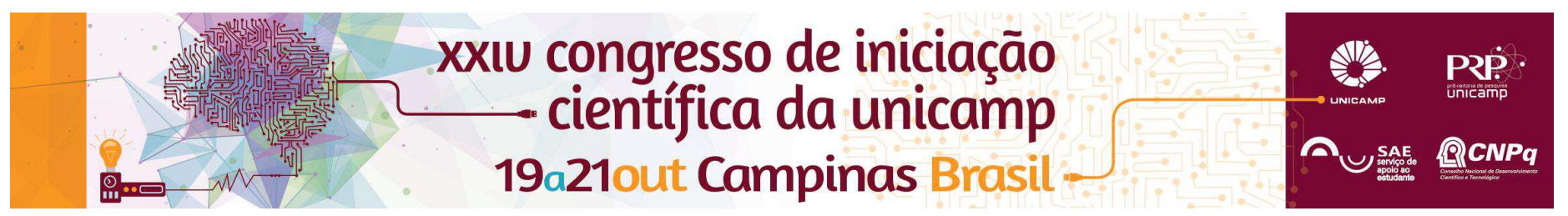

\title{
Estudo de sistemas de juntas em Light Steel Frame para prevenção de patologias.
}

\author{
Angelo Stasievski Filho*, Carlos E. M. Gomes.
}

\section{Resumo}

A crescente utilização do sistema construtivo Light Steel Frame tem como obstáculo o revestimento utilizado, o qual exposto às intempéries do meio externo, sofre de patologias como fissuras, sendo que as técnicas alternativas são de elevado custo, o presente projeto tem como objetivo analisar uma nova possibilidade acessível de revestimento argamassado que não sofra das mesmas adversidades mencionadas.

\section{Palavras-chave:}

Light Steel Frame, juntas, construção a seco.

\section{Introdução}

O Light Steel Frame é muito utilizado em países desenvolvidos, tendo grande expansão de seu uso em certas nações em desenvolvimento como o Chile. No Brasil, sua utilização se dá especialmente como solução para diminuir o deficit habitacional do país.

A adoção de sistemas construtivos industrializados na produção de moradias popupalres é uma das políticas públicas do Governo Federal, especialmente o Ministério das Cidades. Dentre os sistemas adotados está o Light Steel Frame, constituído de perfis metálicos para produção de painéis com fechamento em painéis OSB e/ou placas cimentícias. No entanto, o sistema de juntas ainda não é resolvido e patologias têm surgido, especialmente fissuras entre placas, comprometendo a estética, desempenho e qualidade destas unidades habitacionais. Neste sentido são metas deste projeto o estudo da variação dimensional das placas cimentícias, o estudo do sistema de juntas a ser empregado e, em especial, 0 estudo do desempenho do revestimento externo em condições laboratoriais e expostos ao ambiente. Atualmente, se tem empregado argamassas poliméricas ou texturas capazes de suportar tais movimentações, porém, onerando significativamente o custo de produção. Pretende-se, assim, verificar a adoção de argamassas mistas de cimento e cal reforçadas por telas de arame losangular em conjunto com adoção da técnica de projeção. Dessa forma, pode ser possível a exucução de um revestimento compatível com o trabalho das juntas, podendo representar além da redução de custos, ausência de patologias, melhor desempenho e qualidade no acabamento das moradias populares em Light Steel Frame.

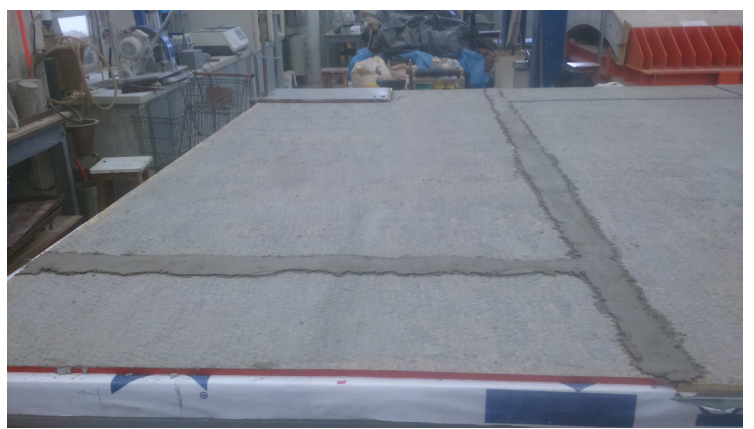

Figura 1. Painel após aplicação de argamassa nas juntas (tela de fibra de vidro álcali-resistente) com 0 chapisco aparente.

\section{Resultados e Discussão}

A presente pesquisa se baseia na análise de um protótipo de Light Steel Frame, bem como a construção de um painel de $9 \mathrm{~m}^{2}$ com revestimento constituído por: manta Tyvek, placa OSB, tela de fibra de vidro álcali-resistente aplicada nas juntas das placas OSB, tela de arame losangular, argamassa de reventimento para alvenaria $\mathrm{e}$ argamassa com aditivo de base látex estireno-butadieno. $A$ montagem foi feita com o painel deitado para posteriormente ser levantado e exposto ao ambiente externo.

Até o pressente momento foi possível observar a viabilidade desse revestimento, especialmente em ambientes internos.

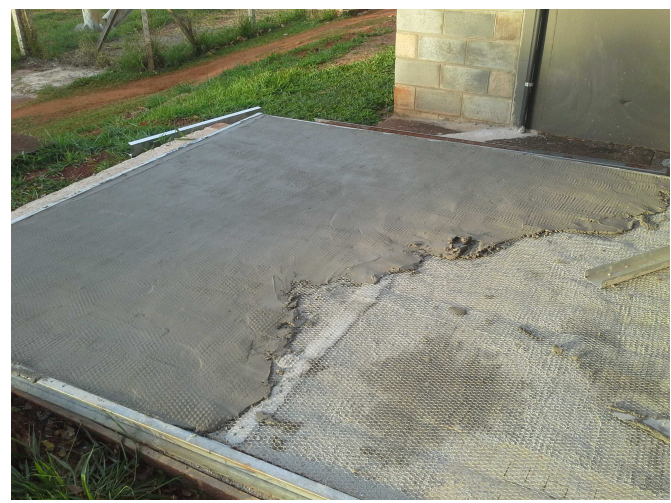

Figura 2: Aplicação de argamassa de revestimento no painel (sobre a tela de arame losangular).

\section{Conclusões}

A pesquisa está em andamento, portanto análises ainda não foram concluídas.

\section{Agradecimentos}

Ao Projeto Procad (CAPES), pela bolsa de iniciação científica e às Intituições da UFRGS e UNICAMP pela oportunidade oferecida.

GOMES, C. E. M et al. Light Steel Frame: Construção industrializada a seco para habitação popular-práticas sustentáveis. Curitiba 2013.

FAGIANI, L. Estudo Comparativo dos Sistemas Construtivos: Steel Frame,

Concreto PVC e Sistema Convencional. UniFeb, Barretos, 2009. 